\title{
EplT4 proteinaceous elicitor produced in Pichia pastoris has a protective effect against Cercosporidium sofinum infections of soybean leaves
}

Yun Wang ${ }^{\mathrm{a}}$, Jinzhu Song ${ }^{\mathrm{a}}$, Yingjie Wu $\mathrm{a}^{\mathrm{a}}$, Margaret Odeph ${ }^{\mathrm{a}}$, Zhihua Liu ${ }^{\mathrm{a}}$, Barbara J.

Howlett ${ }^{\mathrm{b}}$, Shuang Wang ${ }^{\mathrm{c}}$, Ping Yang ${ }^{\mathrm{a}}$, Lin Yao ${ }^{\mathrm{a}}$, Lei Zhao ${ }^{\mathrm{a}}$, Qian Yang ${ }^{\mathrm{a}^{*}}$

${ }^{\mathrm{a}}$ Department of Life Science and Engineering, Harbin Institute of Technology, Harbin 150001,China

${ }^{\mathrm{b}}$ School of Botany, The University of Melbourne, 3010 Melbourne, Victoria, Australia

${ }^{\mathrm{C}}$ Institute of Soil Fertilizer and Environment Resources, Heilongjiang Academy of Agricultural Sciences.

*Corresponding author

Phone: 86-0451-86402652

Fax: 86-0451-86412952

Email: yangqian84@yahoo.com 


\section{Abstract}

A cDNA library was constructed from the mycelium of Trichoderma asperellum T4 and a highly expressed gene fragment named EplT4 was found. In order to find a more efficient and cost-effective way of obtaining EplT4, this study attempted to produce EplT4 by using a Pichia pastoris (P. pastoris) expression system. The gene encoding EplT4, with an additional 6-His tag at the C-terminus, was cloned into the yeast vector pPIC9K and expressed in the $P$. pastoris strain GS115 to obtaining more protein for the further research. Transformants of P. pastoris were selected by PCR analysis and the ability to secrete high levels of the EplT4 protein was determined. The optimal conditions for induction were assayed using the shake flask method and an enzyme-linked immunosorbent assay (ELISA). The yield of purified EplT4 was approximately $20 \mathrm{mg} / \mathrm{L}$ by nickel affinity chromatography and gel-filtration chromatography (GFC). Western blot and MALDI-TOF-MS (matrix-assisted laser desorption/ionization time-of-flight mass spectrometer) analysis revealed that the recombinant EplT4 was expressed in both its monomers and dimers. Soybean leaves treated with the EplT4 monomer demonstrated the induction of glucanase, chitinase III-A, cysteine proteinase inhibitor and peroxidase genes. Early cellular events in plant defense response were also observed after incubation with EplT4. Soybean leaves protected by EplT4 against the pathogen Cercosporidium sofinum (Hara) indicated that EplT4 produced in P. pastoris was biologically active, and would be potentially useful for improving food security.

Keywords EplT4 elicitor; Trichoderma asperellum; Pichia pastoris; Soybean; Induced resistance. 


\section{Introduction}

2 Trichoderma spp. fungi have long been recognized as biocontrol agents of plant

3 diseases and are widely used as commercial biofungicides for the control of soil-

4 borne and foliar pathogens [1]. Regular use of Trichoderma spp. has provided an

5 economic advantage for food security because of the reduced need to use pesticides.

As Trichoderma spp. grow and proliferate, they have evolved numerous

7 mechanisms for attacking other fungi. The principal mechanisms for biocontrol have been assumed to be those primarily acting upon pathogens including mycoparasitism,

9 antibiosis, and competition for resources and space [2, 3]. Some Trichoderma spp. are

10 able to colonize the intercellular spaces of plant roots up to the cortex layer. Root

11 colonization by Trichoderma spp. is frequently associated with the induction of both

12 local and systemic resistance to pathogen attacks [4-6].

13 Although many reports exist on elicitors produced by beneficial rhizobacteria, 14 since their discovery nearly 30 years ago [7], elicitors involved in systemic resistance 15 triggered by Trichoderma spp. are not well-studied. Induced resistance has been 16 reported for Trichoderma harzianum T39 strain on soybeans [8], a T203 strain on 17 cucumbers [5], and Trichoderma virens on cotton and maize [9, 10]. Cellulose and 18 xylanase from Trichoderma spp. can elicit resistance in plants independently of their 19 degradation activity [11]. The 18-mer peptaibols from T. virens can elicit cucumber 20 defense responses [12]. The dimerization of elicitors from T. virens (which secretes 21 the proteinaceous hydrophobin-like elicitor $\mathrm{Sm} 1$ ) and $T$. atroviride (eliciting plant 22 response-like protein, Epl1) has previously been investigated. Both Seidl and Vargas 23 have proposed that aggregation of the elicitors might control the Trichoderma-plant 24 interaction and block the activation of induced systemic resistance in plants [13, 14]. 

species. A directional cDNA library from the mycelium of $T$. asperellum T4 strain

3 fungi was constructed [15] and a highly expressed gene fragment named EplT4 that is

4 homologous to Epl1 protein in T. atroviride was found. As Epl1 protein in $T$.

5 atroviride is a plant defense response elicitor, which signifies that EplT4 may have

6 the similar function. Given, that high redundancy of a specific cDNA sequence is

7 usually associated with high expression levels, this indicates that it may play an

8 important role in biocontrol. According to sequence analyses, EplT4 belongs to the

9 cerato-platanin (CP) 3-protein family, which consists mainly of proteins produced by

10 fungi that are associated with toxicity and infection processes [16]. The peptides

11 revealed a high similarity to cerato-ulmin, a phytotoxic protein involved in Dutch Elm

12 disease that belongs to the hydrophobin family. Hydrophobins are hydrophobic

13 proteins secreted by many pathogenic fungi. These proteins have the ability to self-

14 assemble into a rodlet structure which is involved in growth and/or developmental

15 processes [17].

16 Purification of native Sm1 protein from $T$. virens results in low protein yield

17 (approximately $150 \mu \mathrm{g} / \mathrm{L}$ ) [16] which limits its wider application to small-scale assays

18 (10 $\mu \mathrm{g}$ EplT4 was needed in each trial). Similar results $(110 \mu \mathrm{g} / \mathrm{L})$ were obtained from

19 purification of T. asperellum T4 (unpublished data). In order to explore the role

20 played by EplT4, for which significant amounts of proteins were needed, this study

21 aimed to produce EplT4 by recombinant methods. Escherichia coli, the most common

22 heterologous protein expression system, does not correctly process many polypeptides

$23[18,19]$. The recombinant CP has been expressed in E. coli and the correct product

24 was obtained only after a refolding step and at low yields [17]. The Pichia pastoris

25 heterologous gene expression system, which has appropriate post-translational 
1 modifications for protein functionality, has been used exclusively to produce high

2 levels of a variety of intracellular and extracellular proteins of interest [20]. $P$.

3 pastoris is a metholotrophic yeast which requires neither complex growth medium nor

4 culture conditions, is genetically relatively easy to manipulate, and has a eukaryotic

5 protein synthesis pathway. Simple purification of secreted recombinant proteins is

6 possible due to the relatively low levels of native secreted proteins [21, 22].

7 Therefore, the aim of this study was to express EplT4 in P. pastoris and demonstrate

8 its elicitation properties in soybean.

$9 \quad$ Materials and methods

10 Materials

12 Pfu DNA polymerase was obtained from Promega (Madison, WI, USA). Restriction 13 endonucleases, T4 DNA ligase, and protein molecular markers were purchased from 14 Fermentas (China). Yeast nitrogen base (YNB) was purchased from Invitrogen. His15 bind column was purchased from Novagen (Madison, WI, USA). Superdex 200 was 16 purchased from G.E. Healthcare (USA). The statistical software package SPSS 17.0 17 (IBM, Armonk, NY, USA) was used for statistical analysis. All other chemicals used 18 were analytical grade reagents unless otherwise stated.

20 Strains and Plant Varieties

22 Biocontrol agent T. asperellum strain T4 was obtained from the China General

23 Microbiological Culture Collection Center (number CGMCC3.14975). P. pastoris

24 expression vector pPIC9K and P. pastoris host strains GS115 (his-mut+) were

25 obtained from Invitrogen. E. coli Top10F' was used for propagation of plasmids 
1 (Invitrogen). Cercosporidium sofinum (Hara) strain 15 (which causes frog eye leaf

2 spot disease on soybeans) and soybean (Glycine max) variety Suinong 10 were

3 provided by the Heilongjiang Academy of Agricultural Sciences, China. The EplT4

4 protein sequence was aligned with other CP proteins available in the GenBank

5 database using the ClustalX (version 1.8) multiple sequence alignment program. The

6 alignment results were manipulated using GeneDoc software (version 2.12).

7 Phylogenetic analysis was performed with the protein sequences aligned by ClustalW

8 using the neighbor-joining algorithm. A phylogenetic tree was generated, and a

9 distance matrix was produced, using the MEGA (version 3.1) program.

11 Construction of $P$. pastoris Expression Plasmid of EplT4

13 Primer design was based on the nucleic acid sequence of EplT4 from published

14 databases (Accession No. HM572232), and the primers P1 and P2 (Table 1) were

15 designed for PCR amplification from cDNA including the completed coding DNA

16 sequence (CDS). The signal peptides were analyzed by Signal P 3.0 server

17 (http://www.cbs.dtu.dk/services/SignalP). The native signal peptides were removed

18 and an additional sequence encoding a 6-His tag was fused at the $3^{\prime}$ end of the EplT4

19 gene for easy purification and detection of the gene product. The amplified EplT4

20 gene was purified using the UNIQ-10 Column Collection Tube Kit and digested with

21 EcoR I and Not I, and ligated with similarly digested pPIC9K. The ligated product

22 was transformed in E. coli Top10F' cells and the positive colonies were selected by

23 colony PCR. Positive transformants were further confirmed by sequencing, using the

24 dideoxy chain-termination method [23]. This strategy placed EplT4 (without its native 
1 N-terminal signal sequence) under the AOX promoter of pPIC9K vector and used the

2 S. cerevisiae signal peptide for secretion out of the cells.

4 Transformation and Screening for EplT4-Productive Clones

6 Sal I was used to linearize 5-10 $\mu \mathrm{g}$ of pPIC9K-EplT4 plasmid DNA, and the linear

7 DNA was then transformed into P. pastoris GS115 cells with an electroporator

8 (Eppendorf: conditions: $1.1 \mathrm{kV}$ ). The electroporated cells were immediately

9 suspended in $1.0 \mathrm{~mL}$ of ice-cold 1.0 M sorbitol and spread on MD plates (1.34\% yeast

10 nitrogen base containing ammonium sulfate and lacking amino acids, $4 \times 10^{-5} \%$

11 biotin, $2 \%$ dextrose, and $1.5 \%$ agar). The His+ transformants resistant to increasing

12 concentrations of G418 were screened according to the manufacturer's protocol

13 (Invitrogen). The "boiling-freezing-boiling" method was used to prepare the $P$.

14 pastoris genomic DNA [24]. His+ transformants were analyzed by PCR using the $\alpha$ -

15 factor primer and 3'-AOX1 primer (Table 1) to investigate whether the EplT4 gene

16 had integrated into the $P$. pastoris genome.

17 For screening EplT4-productive clones, several single colonies of P.pastoris

18 were inoculated into $50 \mathrm{~mL}$ of buffered glycerol-complex medium (BMGY; $1 \%$ yeast

19 extract, $2 \%$ peptone, $100 \mathrm{mM}$ of potassium phosphate, $1.34 \% \mathrm{YNB}, 4 \times 10^{-5} \%$ biotin,

20 and $1 \%$ glycerol, $\mathrm{pH} 6.0$ ) in $250 \mathrm{~mL}$ flasks at $28^{\circ} \mathrm{C}$, with shaking at $220 \mathrm{rpm}$ until an

$21 \mathrm{OD}_{600}$ value of 6 was attained. The cell pellets were harvested and resuspended in 100

$22 \mathrm{~mL}$ of BMMY (1\% yeast extract, $2 \%$ tryptone, $1.34 \%$ YNB, $4 \times 10^{-5} \%$ biotin, $0.5 \%$

23 methanol (v/v) in $100 \mathrm{mM}$ potassium phosphate, $\mathrm{pH}$ 6.0) in $1 \mathrm{~L}$ flask with shaking at

$24220 \mathrm{rpm}$ at $28^{\circ} \mathrm{C}$. The resuspended culture was induced for $96 \mathrm{~h}$ by addition of $100 \%$

25 methanol to a final concentration of $0.5 \%(\mathrm{v} / \mathrm{v})$ every $24 \mathrm{~h}$. The supernatant was 
1 collected by centrifugation at $10,000 \times g$ at $4{ }^{\circ} \mathrm{C}$ for $10 \mathrm{~min}$ and analyzed by Western

2 blot. The primary antibody and secondary antibody were mouse anti His-tag and goat

3 anti mouse $\mathrm{IgG}$, respectively.

5 Optimization of Conditions for Cell Growth and EplT4 Expression

7 To define the optimal conditions for EplT4 expression, different factors that could

8 affect the host cell growth and EplT4 yield were tested, including the time following

9 induction (24, 48, 72, and $96 \mathrm{~h}), \mathrm{pH}$ values (4.0, 5.0, 6.0, and 7.0), and final

10 concentrations of methanol $(0.5 \%, 1.0 \%$, and $2.0 \%)$. The EplT4 yield was determined

11 by an enzyme-linked immunosorbent assay (ELISA). Antibodies used were as 12 described above.

13 For high-level production of EplT4, the highest G418-resistant P. pastoris clone 14 was selected as seed, while the high-cell density fermentation was conducted in a 19

15 L fermenter (NLF, Bioengineering AG, Switzerland) as previously described [25].

16 Glycerol batch fermentation (high-cell density fermentation) was performed 17 according to the Pichia Fermentation Process Guidelines (Version B, 053002). When 18 the initial glycerol was depleted as indicated by a dissolved oxygen spike, glycerol

19 fed-batch fermentation was initiated by starting the fed-batch medium at a rate of 18.4 $20 \mathrm{~mL} \mathrm{~h}^{-1} \mathrm{~L}^{-1}$ of initial medium volume. In the methanol fed-batch phase, temperature, $21 \mathrm{pH}$ and DO (dissolved oxygen concentration) were monitored and maintained at set 22 points of $30^{\circ} \mathrm{C}, \mathrm{pH} 5.0$ and $30-40 \%$, respectively. The $\mathrm{pH}$ was adjusted by the 23 addition of ammonium hydroxide as needed. The growth curve of recombinant $P$. 24 pastoris was determined by weighing the wet weights of the cells from fermentation 
1 mixture taken at $24 \mathrm{~h}$ intervals. In addition, Western blot was employed to assess the expression of EplT4 secreted into the culture medium.

4 Purification and Characterization of the Secreted Recombinant EplT4

6 The entire culture medium obtained from the high-cell density fermentation was

7 harvested by centrifugation at $8,000 \times g$ for $15 \mathrm{~min}$ at $4{ }^{\circ} \mathrm{C}$. The resultant supernatants

8 were precipitated overnight with $80 \%$ ammonium sulfate. The resulting precipitate

9 was then centrifuged at $12,000 \times g$ for $20 \mathrm{~min}$, collected and dissolved in binding

10 buffer of a His-bind column. The protein dissolved in binding buffer was passed

11 through a $0.45 \mu \mathrm{m}$ membrane filter and applied to the His-bind column equilibrated

12 with binding buffer ( $\mathrm{NaCl} 0.5 \mathrm{M}$; Tris $20 \mathrm{mM}$; Imidazole $5 \mathrm{mM}$, and $\mathrm{pH} 7.9)$. After

13 washing with washing buffer $(\mathrm{NaCl} 0.5 \mathrm{M}$; Tris $20 \mathrm{mM}$; Imidazole $60 \mathrm{mM}$, and $\mathrm{pH}$

14 7.9), the recombinant protein was eluted with elution buffer $(\mathrm{NaCl} 0.5 \mathrm{M}$; Tris $20 \mathrm{mM}$;

15 Imidazole 1M, and $\mathrm{pH}$ 7.9). The fractions containing EplT4 were pooled, dialyzed

16 against $10 \mathrm{mM} \mathrm{NH}_{4} \mathrm{HCO}_{3}$ and concentrated to $5 \mathrm{~mL}$. They were then purified further

17 by gel-filtration chromatography (GFC) through a HiPrep 26/60 Sephacryl S-100 HR

$18(16 \times 60 \mathrm{~cm}$; G.E. Healthcare) pre-equilibrated with Tris/ $\mathrm{NaCl}$ buffer (Tris $50 \mathrm{mM}$;

$19 \mathrm{NaCl} 100 \mathrm{mM}, \mathrm{pH}$ 7.0). The column was then eluted with $50 \mathrm{mM}$ Tris and $100 \mathrm{mM}$

$20 \mathrm{NaCl}$ at a flow rate of $1.0 \mathrm{~mL} / \mathrm{min}$. The fractions that showed maximum absorbance at

$21280 \mathrm{~nm}$ were isolated. The purity of protein was assessed by a 15\% SDS-PAGE

22 followed by Coomassie blue staining. The fractions containing recombinant EplT4, as

23 determined by SDS-PAGE, were pooled, dialyzed $\left(10 \mathrm{mM} \mathrm{NH}_{4} \mathrm{HCO}_{3}\right)$ and

24 lyophilized for further experiments. 
Both the bands of EplT4 monomer and its dimer candidate after separation on

2 SDS-PAGE were excised manually and subjected to in-gel trypsin digestion [26]. The

3 digestion products were extracted and prepared for MALDI-MS (matrix-assisted laser

4 desorption/ionization mass spectrometer) analysis. The peptide mass fingerprint was

5 analyzed in a MALDI-TOF MS (matrix-assisted laser desorption/ionization time-of-

6 flight mass spectrometer).

Recombinant EplT4 Activity Tests

10 The production of $\mathrm{H}_{2} \mathrm{O}_{2}$ in two week-old soybean unifoliate leaves was examined 12

$11 \mathrm{~h}$ after application of either EplT4 monomer $(10 \mu \mathrm{g})$ or sterile water (negative

12 control). Drops $(10 \mu \mathrm{g})$ of EplT4 or sterile water were placed on the slightly

13 punctured surface of the leaves. The leaves were then infiltrated with nitro 3,3'-

14 diaminobenzidine (DAB, Sigma), incubated overnight, fixed and cleared in alcoholic

15 lacto-phenol solution [27]. A red-brown precipitate was observed using an Olympus

16 microscope BX-51 (Olympus America Inc.) at ten-fold magnification.

17 To test for autofluorescence, $10 \mu \mathrm{g}$ of EplT4 monomer, $50 \mathrm{nmol}$ of 2,6-

18 dichloroisonicotinic acid (INA, Sigma), or sterile water was applied to soybean leaves

19 as described above. After $12 \mathrm{~h}$ of incubation, the induction of autofluorescence in

20 leaves was observed. Treated leaves were cleared in alcoholic lacto-phenol solution,

21 incubated in 70\% glycerol, and mounted on slides [27]. Microscopy was performed

22 using an Olympus BX-51 fluorescent microscope at twenty-fold magnification

23 (excitation wavelengths from 470 to $490 \mathrm{~nm}$, emission wavelengths from 510 to 550

$24 \mathrm{~nm}$, and a dichroic mirror at $505 \mathrm{~nm}$ ). 
1 C. sofinum (Hara) Resistance Assay of Soybean Leaves

3 C. sofinum (Hara) strain 15 was grown for 10 days on PDA at $28^{\circ} \mathrm{C}$ under constant

4 light. Conidiospores were scraped from plates, filtered through gauze, and washed

5 three times in distilled water, followed by centrifugation for $5 \mathrm{~min}$ at $10,000 \times g$.

6 Conidiospores were counted using a hemacytometer, spore suspension was adjusted

7 to $1 \times 10^{4}$ conidia/mL and Tween 20 was added to a final concentration of $0.005 \%$.

$8 \quad$ Fourteen day-old soybean unifoliate leaves were elicited applying EplT4 (10 $\mu \mathrm{g})$ to

9 the cut petiole and salicylic acid (SA, Sigma) at $30 \mathrm{nmol} / \mathrm{leaf}$ was used as positive

10 control. After $12 \mathrm{~h}$ of incubation at $27^{\circ} \mathrm{C}, 50 \mu \mathrm{L}$ of $C$. sofinum (Hara) conidiospores

11 was placed on the surface of each leaf. The seedlings were incubated in a growth

12 chamber at $27^{\circ} \mathrm{C}$, with a $14 \mathrm{~h}$ photoperiod and $60 \%$ humidity for two weeks. Leaves

13 were photographed with a digital camera (Nikon). Lesion percentage was determined

14 using Image Pro Plus 6.0 software. Each treatment contained five repetitions and the

15 experiment was repeated twice. Data were analyzed by ANOVA and Fisher's PLSD

16 test $(P<0.05)$.

17

18 Expression Analysis of Soybean Defense-Related Genes

20 Real-time quantitative PCR (qPCR) was used to evaluate gene expression in soybean

21 leaves after $12 \mathrm{~h}$ of incubation of EplT4 monomer $(50 \mu \mathrm{g})$ or sterile water (negative

22 control). The leaves were harvested and frozen immediately in liquid nitrogen. Total

23 RNA was extracted using Trizol reagent according to the manufacturer's protocols.

24 Total RNA (5 $\mu \mathrm{g})$ from each sample was reverse-transcribed into cDNA in the

25 presence of oligo(dT) primer. The synthesized cDNA was used as a template for 
1 qPCR. Six pathogenesis-related genes involved in plant defense pathways were

2 selected for expression analysis. Actin 11 was used as an internal reference to

3 normalize the amount of total RNA present in each reaction. All genes and primers

4 used in this study are presented in Table 1 . The expression levels of the genes were

5 calculated from the threshold cycle according to the $2^{-\Delta \Delta C T}$ method [28].

\section{$7 \quad$ Results}

$8 \quad$ Cloning and Expression of EplT4 in P. pastoris

The EplT4 from T. asperellum T4 is a 138 aa protein with a predicted molecular mass

11 of $14.5 \mathrm{kDa}$ (containing signal peptide), and an isoelectric point (pI) of 6.68

12 (Supplement Fig. 1a). A putative signal peptide of 18 aa with a cleavage site between

13 alanine-18 and aspartic acid-19 at its N-terminal and four conserved cysteine residues

14 located in conserved amino acid positions were identified in EplT4 protein

15 (Supplement Fig. 1a). Sequence alignment and phylogenetic tree analysis with

16 homologues from other fungi revealed that EplT4 shows a high level of similarity to

17 the fungal proteins of T. atroviridis and T. virens (Supplement Fig. 1b).

18 The recombinant pPIC9K-EplT4 vector was constructed by inserting complete

19 EplT4 CDS (excluding the secretion tag and with an additional 6-His tag at the $3^{\prime}$ end)

20 into the EcoR I and Not I sites in the pPIC9K vector (Supplement Fig. 2). The

21 resulting vector was transformed into P. pastoris strain GS115, and approximately

22300 transformants were obtained on MD plates. Further screening of the

23 transformants with different concentrations of G-418 yielded five colonies on 0.3

$24 \mathrm{mg} / \mathrm{mL} \mathrm{G}-418$. After a preliminary screening, one transformant that contained the

25 appropriate size of the EplT4 gene insert, and also produced an extracellular protein 
1 in the crude filtrate as analyzed by Western blot (Fig. 1), was selected. The yeast cells

2 harboring an empty pPIC9K vector did not yield the PCR product or the extracellular

3 protein (Fig. 1a lane 2, 1b, lane 4).

High-Cell-Density Fermentation to Produce Recombinant EplT4

7 The optimum time to induce EplT4 expression is shown (Fig. 2a). A significant

8 increase in the amount of recombinant protein was observed with increasing induction

9 time, peaking at $48 \mathrm{~h}$. Therefore, EplT4 was collected at $48 \mathrm{~h}$ after induction. As

10 shown in Fig. $2 \mathrm{~b}$, a pH of 5 was found to be optimal. Because methanol is both the

11 inducer and the sole carbon source of $P$. pastoris, its concentration was fundamental

12 in influencing EplT4 production. As revealed in Fig. 2c, EplT4 yield was similar

13 between concentrations of $0.5 \%$ and $2.0 \%$. However, both cell growth and EplT4

14 yield declined at a methanol concentration of $5.0 \%$ (data not shown). As a result the

15 concentration of methanol in the culture medium was maintained at $1 \%$.

16 To obtain enough recombinant EplT4 for the evaluation of its bioactivity, high-

17 cell density fermentation of the selected clone was conducted in a $19 \mathrm{~L}$ fermenter with

$185 \mathrm{~L}$ initial volume. After fed-batch fermentation, the wet weight of the cells reached

$19200 \pm 25 \mathrm{~g} / \mathrm{L}$ ( $40 \mathrm{~h}$ post-seeds inoculation), and the induction medium was gradually

20 added. As shown in Supplement Fig. 3, two protein bands were observed in Western

21 blot analysis of the fermentation supernatant at different induction times. Because the

22 optimum time to induce EplT4 expression was found to be $48 \mathrm{~h}$, the supernatant at 48

$23 \mathrm{~h}$ was collected for purification. The yield of EplT4 from the fermentor was $50 \mathrm{mg} / \mathrm{L}$

24 which was 1.56 times more than the yield from the shaker flask $(32 \mathrm{mg} / \mathrm{L})$. 
1 Purification and Characterization of Recombinant EplT4

3 Due to the presence of the 6-His tag, the secreted EplT4 was purified by nickel

4 affinity chromatography, resulting in two primary bands (Fig. 3b, lane 2). The

5 purification of EplT4 by gel filtration chromatography on Sephacryl S-100 HR is

6 displayed in Fig. 3a. Fractions corresponding to EplT4 monomer were identified

7 spectrophotometrically at $\mathrm{OD}_{280}$ (Fig. 3b, lane 3). This was later confirmed by

8 Western blot using the anti-His-tag antibody. In contrast to the calculated molecular

9 weight of $13.4 \mathrm{kDa}$ (without signal peptide and adding 6-His tag), the recombinant

10 protein migrated as a band with an apparent molecular mass of approximately 17.0

$11 \mathrm{kDa}$. The final yield of EplT4 monomer obtained from $1 \mathrm{~L}$ of basal salts medium

12 induced by $1 \%$ methanol was approximately $20 \mathrm{mg} / \mathrm{L}$ using Bradford assays [29]. To

13 investigate whether EplT4 could self-associate into higher order to assemble a

14 homodimer, similar to Epl1 and Sm1, the monomer and dimer were subjected to in-

15 gel tryptic digestion. The peptide mass fingerprint of both isoforms revealed similar

16 patterns, with the peptides at $\mathrm{m} / \mathrm{z} 1414.8,1718.4,2304.9$ and 2505.2 existing in both

17 isoforms (Fig. 4).

19 EplT4 Induces Plant Defense Reactions in Soybean

21 EplT4 belongs to the CP protein family, which is usually involved in phyto-

22 pathological phenomena and immunological reactions. The production of hydrogen

23 peroxide and accumulation of phenolic compounds that usually associate with

24 autofluorescence are the early response signals in elicitor recognition [30, 31]. The

25 ability of recombinant EplT4 to elicit these responses was tested and the production of 
1 hydrogen peroxide in soybean leaves after exposure to EplT4 was examined.

2 Application of EplT4 $(10 \mu \mathrm{g})$ resulted in the production of hydrogen peroxide around

3 the puncture. A brownish-red precipitate generated by polymerization of the hydrogen

4 peroxide with nitro 3,3'-diaminobenzidine in the treated tissues was observed (Fig. 5).

5 The induction of autofluorescence was tested in soybean unifoliate leaves. An

6 insignificant response was found in sterile water-treated leaves (negative control),

7 which was probably due to the wounding of the leaf during the treatment application.

8 High levels of autofluorescence were apparent after treatment with $10 \mu \mathrm{g}$ of EplT4

9 monomer or $50 \mathrm{nmol}$ of INA (SA analog) used as the positive control (Fig. 6).

11 EplT4 Induces Resistance Against a Soybean Pathogen

13 In order to assess the disease resistance of soybeans, the leaves pretreated with EplT4 14 were inoculated with $C$. sofinum (Hara) strain 15 for $12 \mathrm{~h}$. SA and sterile water were 15 used as positive and negative control, respectively. Control plants treated with water 16 began showing symptoms in the form of frogeye spots within seven days. Disease assessment was conducted after fourteen days following the inoculation as shown in

18 Fig. 7. In contrast to frogeye spots observed in water-treated leaves, disease protection 19 was evident in leaves treated with EplT4 and SA, since almost no lesion development 20 could be observed in those plants (Fig. 7, a). The mean lesion area exhibiting 21 symptoms was significantly higher in control plants $(5.17 \%)$ than in plants treated 22 with EplT4 $(0.75 \%)$ or SA $(0.42 \%)$ (Fig. 7, b). The results confirmed that purified 23 EplT4 was able to induce resistance to $C$. sofinum (Hara) in soybeans. 
2 The expression of these pathogenesis-related protein genes in leaves treated with

3 EplT4 was examined. Two week-old soybean seedlings grown in a gnotobiotic

4 system were used. PR-proteins have been classified into several groups based on their

5 amino acid sequences and biochemical functions. The expression of the PR-proteins

6 either singly or in combination appears to improve plant resistance. PR-protein genes

7 from different families were selected. Gene expression $12 \mathrm{~h}$ after application of EplT4

8 monomer to soybean leaves was shown in Fig. 8. Application of EplT4 resulted in up-

9 regulation of glucanase (GLU), chinase III-A (Chi III-A), cysteine proteinase

10 inhibitor (CPI) and peroxidase gene expression compared to the control (treatment

11 with sterile water). Chinase I (Chi I) and Thaumatin-like protein (TLP) were

12 constitutively expressed in the leaves and showed no response to the EplT4 treatment.

13 In summary, the treatment of plant leaves with EplT4 resulted in inducing some

14 defense-related genes in soybean variety Suinong 10.

16 Discussion

17 P. pastoris has been developed as an excellent host for heterologous protein

18 expression owing to its high expression levels, efficient secretion, proper protein

19 folding and the potential for a very high-cell density fermentation [32]. The

20 expression levels of the EplT4 protein in T. asperellum T4 was low, which is a

21 limitation for large-scale production. In this study, the gene encoding EplT4 into the

22 pPIC9K vector was subcloned and the recombinant protein in P. pastoris expressed.

23 After induction by methanol, EplT4 protein was secreted into the culture supernatant.

24 The optimal conditions for EplT4 expression in shake flask include induction for 48

$25 \mathrm{~h}$, and a culture pH of 5.0 (Fig. 2a, b). Because the shake flask is an open system and 
1 the methanol inducer could easily evaporate, the protein yield did not change when

2 different amounts of the inducer were added (Fig. 2c). To obtain sufficient

3 recombinant EplT4, high-cell density fermentation was conducted in a fermenter.

$4 \quad$ EplT4 was purified to homogeneity by nickel affinity chromatography and gel-

5 filtration chromatography. Approximately $20 \mathrm{mg}$ of purified target protein could be

6 obtained from $1 \mathrm{~L}$ of culture. Previous work focusing on a related protein, Sm1 from

$7 \quad T$. virens has produced a higher yield than this protein $(55 \mathrm{mg})$ due to less dimers

8 being formed [33]. The monomer of EplT4 showed significant elicitor activity to

9 soybean Suinong 10 against C. sofinum (Hara) strain 15.

10 The molecular weight of recombinant EplT4 was approximately $17.0 \mathrm{kDa}$, which

11 was larger than the predicted value $(13.4 \mathrm{kDa})$. The reasons for the higher molecular

12 mass of EplT4 may be due to post-translational modification by glycosylation. Since

13 the $\alpha$-factor signal sequence for secretion was fused to the $\mathrm{N}$-terminus sequence of

14 EplT4, an N-terminal extension can result from the inefficient cleavage due to the

15 occlusion of the cleavage site on the secreted protein from the peptidase [34]. A

16 similar phenomenon was observed with expression of the other protein from the $\mathrm{CP}$

17 protein family in P.pastoris [17, 33]. The recombinant EplT4 produced by P. pastoris

18 could self-assemble into a dimer (Fig. 3, b), as confirmed by Western blot

19 (Supplement 3) and also protein fingerprinting with MALDI-TOF MS (Fig. 4). The

20 dimer was insoluble in a boiling solution containing $10 \mathrm{~g}$ of sodium dodecyl sulfate

21 (SDS) in $1 \mathrm{~L}$ of $0.1 \mathrm{M}$ sodium phosphate buffer ( $\mathrm{pH}$ 7.0). This property is similar to

22 that of hydrophobic proteins, which have the ability to self-assemble [35]. Sm1 and

23 Epl1 have different abilities to induce plant defense responses due to a small number

24 of amino-acid differences that determine dimerization [14]. EplT4 is more similar to

25 Epl1 than Sm1 (Supplement figure 1, b) in that it may cause EplT4 forming dimers 
1 more easily. In addition, the results of this study have showed that EplT4 can

2 assemble into its dimer at a relatively low level when in low concentration (Fig. 1b).

3 In contrast, the dimer became the main component when high levels of protein were

4 generated by high-cell-density fermentation (Fig. 3b Lane 1 and Supplement 3). The

5 dimer of EplT4 did not show any elicitor activity to soybean (data not shown).

6 However, these aggregates require further investigation to clarify their mechanisms.

7 It is known that accumulation of reactive oxygen species is one of the early

8 cellular events in plant defense responses. EplT4 induced production of $\mathrm{H}_{2} \mathrm{O}_{2}$ in

9 soybean leaves (Fig. 5) without causing hypersensitive response-associated necrotic

10 lesions (Fig. 6a). It has been reported that accumulation of reactive oxygen species is

11 not necessarily associated with hypersensitive response [36, 37]. This is different to

12 what has been observed for CP-proteins from Ceratocystis fimbriata [17],

13 Magnaporthe grisea [38] and Botrytis cinerea [39]. The proposal is that these

14 pathogens would actively stimulate hypersensitive response in plants with the purpose

15 of generating dead tissue to grow. EplT4 induced accumulation of phenolic

16 compounds when applied to soybean leaves. Accumulation of phenolic compounds

17 usually associated with autofluorescence is an example of another type of plant

18 response to pathogens. A prominent autofluorescence response was observed

19 indicating callose was generated around the treated region [40].

20 The protection by purified EplT4 of soybean leaves against $C$. sofinum (Hara), a

21 common and destructive pathogen of soybeans in China, was investigated. The results

22 of this study showed that EplT4 was able to protect soybean leaves from infection by

23 C. sofinum (Hara). The disease in EplT4-pretreated or SA- pretreated leaves was

24 strongly reduced and lesions were minimal. Because humidity is necessary for $C$.

25 sofinum (Hara) to infect soybeans, the seedlings were cultured in a growth chamber 
1 with $60 \%$ humidity. We found that soybean variety Suinong 10 , which is normally

2 susceptible to C. sofinum (Hara) strain 15, was not diseased when grown below $10 \%$

3 humidity.

4 Due to the fact that PR proteins are usually used as markers of plant responses to

5 pathogens or their elicitors, six PR proteins belonging to different families were

6 chosen. In this study, GLU, chi III-A, cysteine proteinase inhibitor and peroxidase

7 genes were highly induced in response to EplT4 (Fig. 8). Interestingly, chi III-A did

8 not show a response to EplT4, whereas chi I indicated that the two genes may play

9 different roles in plant-pathogen interactions [41, 42]. Thaumatin-like protein gene

10 expression did not increase after being induced for $12 \mathrm{~h}$. It has been reported that

11 thaumatin-like protein gene expression in the stem and leaf was maintained at a

12 constant level until $24 \mathrm{~h}$ when it was induced under stress [43].

13 In summary, this study has revealed that a methylotrophic yeast-inducible system

14 is suitable for the high-level expression of the proteinaceous elicitor EplT4, as the

15 yield increased by approximately180-fold. Although some additional residues were

16 imported into the recombinant EplT4 using alpha factor as signal peptide and 6-His-

17 tag for protein purification, the activity of EplT4 was not affected. EplT4 dimer

18 formation is concentration dependent; the higher level of dimer is due to higher

19 expression levels in the fermentor compared to the shaker flask cultures. The property

20 that EplT4 is able to induce plant immune response without necrosis makes it possible

21 for further applications. Overall, this efficient, cost-effective expression system may

22 open new methods for the possible practical applications of EplT4 in high-level plant

23 growth production systems, thereby improving food security. 


\section{Acknowledgments}

2 This work was supported by the National High Technology Research and

3 Development Program of China (2011AA10A205), the Significant Scientific and

4 Technical Project of Heilongjiang Province, China (GA08B101) and the Natural

5 Science Foundation of Heilongjiang (C201118). Thanks also go to KI Tull and C

6 Luprasong from the Faculty of Pharmacy, Rangsit University for editorial assistance

7 with this paper.

8 


\section{References}

2

3 1. Verma M., Brar S. K., Tyagi R. D., Surampalli R. Y., \& Valéro J. R. (2007).

4 Biochemical Engineering Journal, 37, 1-20.

2. Harman G. E. (2006). Phytopathology, 96, 190-194.

3. Harman G. E., Herrera-Estrella A. H., Horwitz B. A., \& Lorito M. (2012). Microbiology, 158, 1-2.

4. Shoresh M., Yedidia I., \& Chet I. (2005). Phytopathology, 95, 76-84.

5. Yedidia I., Benhamou N., \& Chet I. I. (1999). Applied and Environmental Microbiology, 65, 1061-1070.

6. Yedidia I., Shoresh M., Kerem Z., Benhamou N., Kapulnik Y., \& Chet I. (2003). Applied and Environmental Microbiology, 69, 7343-7353.

7. Kloepper J., Schroth M., \& Miller T. (1980). Phytopathology, 70, 1078-1082.

8. De Meyer G., Bigirimana J., Elad Y., \& Höfte M. (1998). European Journal of Plant Pathology, 104, 279-286.

9. Hanson L. E. (2000). Journal of Cotton Science, 4, 224-231.

10. Djonovic S., Vargas W. A., Kolomiets M. V., Horndeski M., Wiest A., \& Kenerley C. M. (2007). Plant Physiology, 145, 875-889.

11. Rotblat B., Enshell-Seijffers D., Gershoni J. M., Schuster S., \& Avni A. (2002). Plant Journal, 32, 1049-1055.

12. Viterbo A., Wiest A., Brotman Y., Chet I., \& Kenerley C. (2007). Molecular Plant Pathology, 8, 737-746.

13. Seidl V., Marchetti M., Schandl R., Allmaier G., \& Kubicek C. P. (2006). FEBS Journal, 273, 4346-4359.

14. Vargas W. A., Djonovic S., Sukno S. A., \& Kenerley C. M. (2008). Journal of Biological Chemistry, 283, 19804-19815. 
1 15. Djonovic S., Pozo M. J., Dangott L. J., Howell C. R., \& Kenerley C. M. (2006). Molecular Plant-Microbe Interactions, 19, 838-853.

16. Liu Z., Yang X., Sun D., Song J., Chen G., Juba O., \& Yang Q. (2010). Molecular Biology Reports, 37, 3673-3681.

17. Carresi L., Pantera B., Zoppi C., Cappugi G., Oliveira A. L., Pertinhez T. A.,

18. Terpe K. (2006). Applied Microbiology and Biotechnology, 72, 211-222.

19. Wang Y., Song J. Z., Yang Q., Liu Z. H., Huang X. M., \& Chen Y. (2010). Applied Biochemistry and Biotechnology, 162, 843-854.

11 20. Daly R., \& Hearn M. T. (2005). Journal of Molecular Recognition, 18, 119-138.

12 21. Cregg J. M., Vedvick T. S., \& Raschke W. C. (1993). Nature Biotechnology, 11, 905-910.

22. Macauley-Patrick S., Fazenda M. L., McNeil B., \& Harvey L. M. (2005). Yeast,

26. Shevchenko A., Henrik Tomas J. H., Olsen J. V., \& Mann M. (2007). Nature

Protocols, 1, 2856-2860. 22, 249-270.

23. Sambrook J., \& Russell D. (2001) Molecular Cloning: A Laboratory Manual, 3rd ed., Cold Spring Harbor Laboratory, New York.

24. Adamska M., Leoñska-Duniec A., Maciejewska A., Sawczuk M., \& Skotarczak B. (2011). Folia Biologica-Krakow, 59, 115-120.

25. Plantz B. A., Sinha J., Villarete L., Nickerson K. W., \& Schlegel V. L. (2006). Applied Microbiology and Biotechnology, 72, 297-305.

27. Fitzgerald H. A., Chern M. S., Navarre R., \& Ronald P. C. (2004). Molecular Plant-Microbe Interactions, 17, 140-151. 
1 28. Livak K. J., \& Schmittgen T. D. (2001). Methods, 25, 402-408.

2 29. Bradford M. M. (1976). Analytical Biochemistry, 72, 248-254.

3 30. Dixon R. A., Harrison M. J., \& Lamb C. J. (1994). Annual Review of Phytopathology, 32, 479-501.

5 31. Hutcheson S. W. (1998). Annual Review of Phytopathology, 36, 59-90.

6 32. McHunu N. P., Singh S., \& Permaul K. (2009). Journal of Biotechnology, 141, 26-30.

33. Buensanteai N., Mukherjee P. K., Horwitz B. A., Cheng C., Dangott L. J., \& Kenerley C. M. (2010). Protein Expression and Purification, 72, 131-138.

34. De Schutter K., Lin Y. C., Tiels P., Van Hecke A., Glinka S., Weber-Lehmann J., Rouze P., Van de Peer Y., \& Callewaert N. (2009). Nature Biotechnology, 27, $561-566$.

36. Baker C. J., \& Orlandi E. W. (1995). Annual Review of Phytopathology, 33, 299321.

37. Glazener J. A., Orlandi E. W., \& Baker C. J. (1996). Plant Physiology, 110, 759763.

38. Yang Y., Zhang H., Li G., Li W., Wang X., \& Song F. (2009). Plant Biotechnology Journal, 7, 763-777.

21 39. Frias M., Gonzalez C., \& Brito N. (2011). New Phytologist, 192, 483-495.

22 40. Heath M. C. (2000). Plant Molecular Biology, 44, 321-334.

23 41. Watanabe A., Nong V. H., Zhang D., Arahira M., Yeboah N. A., Udaka K., \& Fukazawa C. (1999). Bioscience Biotechnology and Biochemistry, 63, 251-256. 
1 42. Gijzen M., Kuflu K., Qutob D., \& Chernys J. T. (2001). Journal of Experimental

2

3

4

5

6

7

8

9

10

11

12

13

14

15

16

17

18

19

20

21

22

23

24

25

26

27

28

29

30

31

32

33

34

35

36

37 Botany, 52, 2283-2289.

43. Onishi M., Tachi H., Kojima T., \& Shiraiwa M. (2006). Plant Physiology and Biochemistry, 44, 574-580.

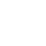

.

(

1

13

15

17

8

0

(2)

3

5

.

28

.

31

. 


\section{Figures Legends}

2

3

Fig. 1 Confirmation of Pichia transformant by colony PCR and Western blot. (a) Agarose gel of EplT4 amplified by PCR using $\alpha$-factor primer and 3' AOX1 primer. Lane $M$ molecular marker (DNA ladder $2 \mathrm{~kb}$, Takara); lane 1 positive transformant GS115/pPIC9K-EplT4; lane 2 Pichia transformed with empty vector GS115/pPIC9K. (b) Western blot of extracellular production of recombinant EplT4 in transformants induced by $1 \%$ methanol after $24 \mathrm{~h}$ and $48 \mathrm{~h}$ incubation. Lane 4 negative control GS115/pPIC9K (48 h); lanes 5 and 6 GS115/pPIC9K-EplT4 (12 h and $48 \mathrm{~h}$, respectively). Arrow indicates the position of EplT4

Fig. 2 Optimal conditions of EplT4 expression in P. pastoris. (a) Expression level of EplT4 in P. pastoris over four days incubation with induction by methanol. (b) Expression level of EplT4 at different pH. (c) Expression level of EplT4 induced by different concentrations of methanol

Fig. 3 Purification of EplT4 from $P$. pastoris by affinity chromatography and gel filtration chromatography. (a) GFC separated P.pastoris into the EplT4 monomer and dimer. (b) The major bands of EplT4 proteins were analyzed by SDS-PAGE followed by Coomassie blue staining. Lane $M$ marker; lane 1 supernatant from medium; lane 2 protein obtained by affinity chromatography; lane 3 EplT4 monomer protein obtained by GFC

Fig. 4 Comparison of the MS polypeptide fingerprint of the EplT4 dimer (a) and monomer (b) after tryptic digestion. Both isoforms were digested in gel, and the polypeptides were analyzed by MALDI-TOF MS

Fig. $5 \mathrm{H}_{2} \mathrm{O}_{2}$ accumulation in soybeans. (a) Soybean leaves were treated with sterile $\mathrm{H}_{2} \mathrm{O}$ (negative control) and (b) treated with EplT4 (10 $\left.\mu \mathrm{g}\right)$. Treated tissues were harvested $12 \mathrm{~h}$ after treatment, and excised leaves were infiltrated with a solution of 3,3'-diaminobenzidine (DAB). In the presence of $\mathrm{H}_{2} \mathrm{O}_{2}$, DAB polymerized, forming a dark red-brown precipitate. Microscopy was performed using Olympus microscope BX-51 (Olympus America Inc.) at ten-fold magnification. Arrow indicates the application area

Fig. 6 Induction of autofluorescence in soybean leaves. (a) Bright-field image and (b) Fluorescence of soybean leaves. Droplets of sterile $\mathrm{H}_{2} \mathrm{O}$ (negative control), EplT4 (10 $\mu \mathrm{g}$ ), or INA (50 nmol, positive control) were placed on the upper surface of slightly punctured leaves. The presence of autofluorescence in treated cotyledons was assessed after $12 \mathrm{~h}$ of incubation. Micrographs are centered on the treated region surrounding the application area (indicated by arrows). Microscopy was performed using Olympus BX-51 fluorescent microscope with excitation from 470 to $490 \mathrm{~nm}$, emission from 510 to $550 \mathrm{~nm}$, and 20-fold magnification 
Fig. 7 Effect of EplT4 application on fungal disease protection. Soybean leaves were inoculated with $C$. sofinum $12 \mathrm{~h}$ after applying a 50- $\mu$ ldroplet of sterile $\mathrm{H}_{2} \mathrm{O}$ (negative control), EplT4 (10 $\mu \mathrm{g} / \mathrm{leaf})$, or salicylic acid (SA; $30 \mathrm{nmol} / \mathrm{leaf}$, positive control) to the cut petiole. (a) The mean lesion areas caused by each of the three treatments were evaluated and photographed 10 days post-inoculation. (b) The graph illustrates the levels of disease protection observed in each treatment. Each bar represents the mean \pm standard error of 10 plants. Columns with letter in common did not differ significantly according to Fisher's protected least significant difference test at a significance level of $P<0.05$

Fig. 8 Expression analysis of soybean defense-related genes. GLU (Beta-1,3glucanase), Chi I (chitinase I), Chi III-A (chitinase III-A), TLP (Thaumatin-like protein), CPI (cysteine proteinase inhibitor). The relative expression levels are equal to their expression after incubation with EplT4 divided by their expression level after being treated with sterile $\mathrm{H}_{2} \mathrm{O}$

\section{Supplemental Figures}

Supplemental Fig. 1 Alignment and phylogenetic tree analysis of EplT4. (a) Alignment of EplT4 with other known fungal proteins. Fungal proteins used for alignment were from Trichoderma asperellum T4 (ADP09352), Trichoderma virens (Q1KHY4) and Trichoderma atroviridis (DQ464903). Signal peptides at N-terminal are indicated by a line below the sequences. Four conserved cysteines are indicated by filled triangles. (b) Phylogenetic tree analysis of EplT4 with other proteins from various fungal species. Phylogenetic tree was constructed using CLASTALW program in MEGA software. The fungal proteins used were from Trichoderma asperellum T4 (ADP09352), Trichoderma virens (Q1KHY4), Trichoderma atroviridis (DQ464903), Ceratocystis platani(ABM63513), Auricularia delicate (EJD54220), Fomitiporia mediterranea (EJD01882), Ceratocystis fimbriata (ABM63507), Colletotrichum higginsianum (CCF39177), Aspergillus oryzae (Q2UF42), Emericella nidulans (Q5AZK7), Gibberella zeae (Q5PSV7), Gibberella pulicaris (Q5PSV6) and Leptosphaeria maculans(Q8J0U4)

Supplemental Fig. 2 Schematic description of the construct pPIC9K-EplT4. (a) Sequence of EplT4 gene cloned into pPIC9K. (b) Amplified EplT4 cDNA. Lane $M$ molecular marker (DL2000); lane 1 EplT4 cDNA

Supplemental Fig. 3 Western blot of recombinant EplT4 from high-cell-density fermentation. Lanes 1-5 supernatant from medium at 0 h, 24 h, 48 h, $72 \mathrm{~h}$ and $96 \mathrm{~h}$, respectively 


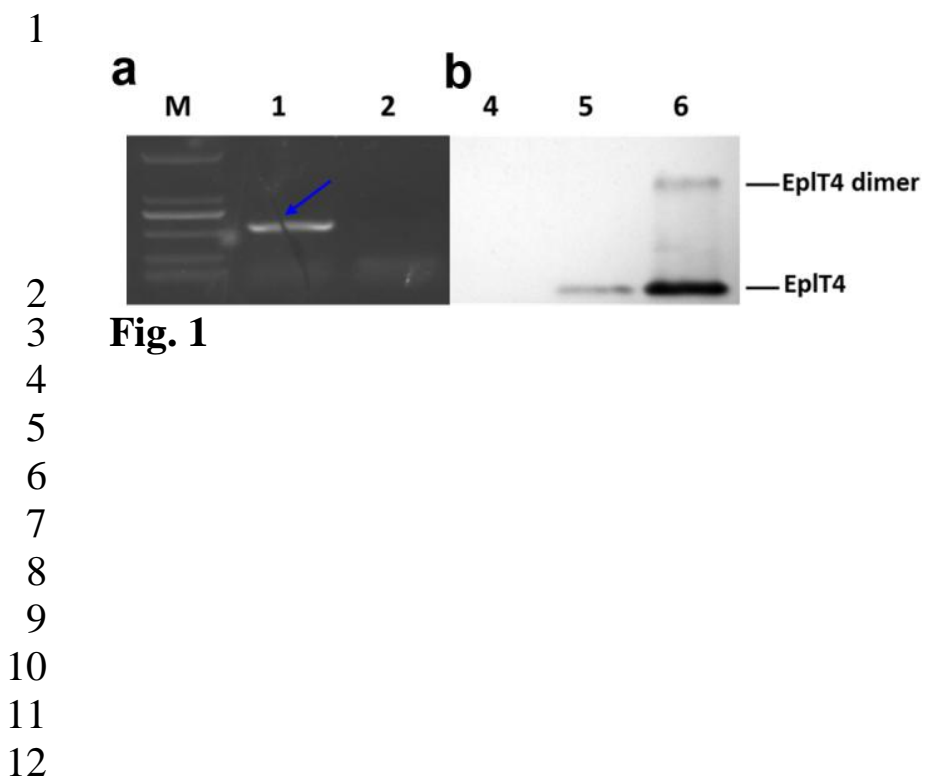


a

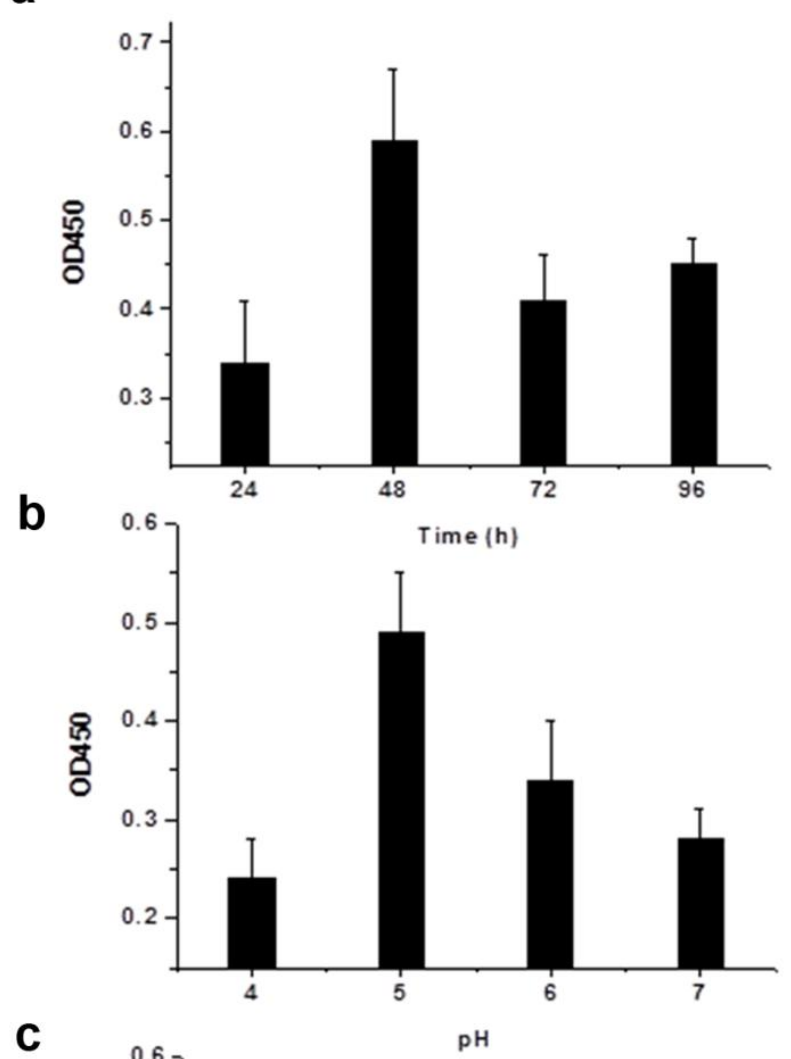

C

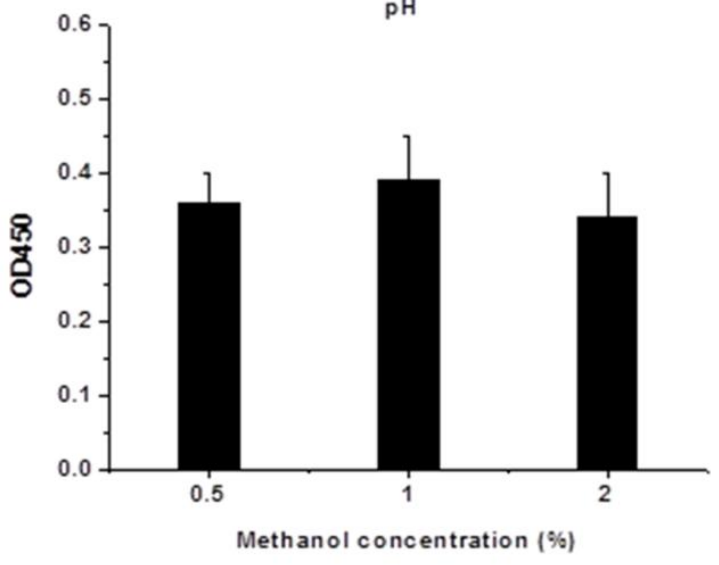

2 Fig. 2

3

4

a

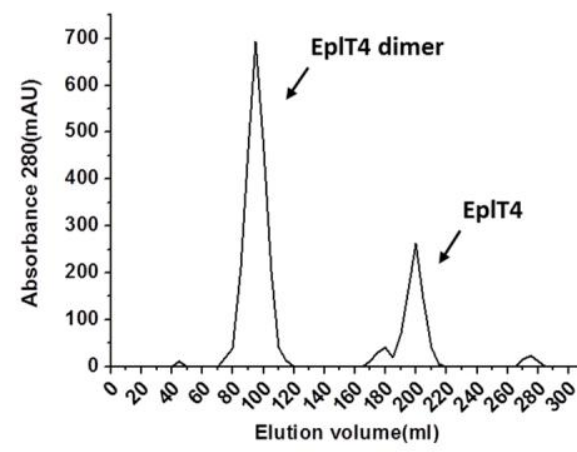

b

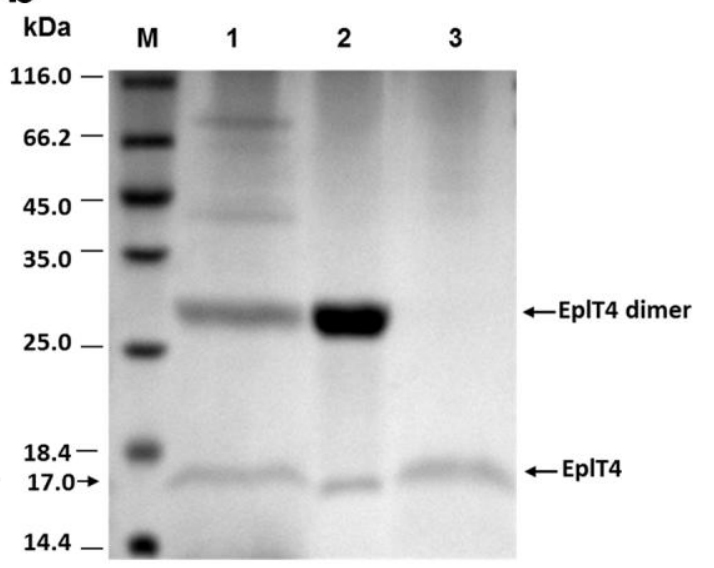


Fig. 3

2

3

4

5

6

7

8

9

10

11

12

13

14

15

16

17

18

a

19

20

Fig. 4

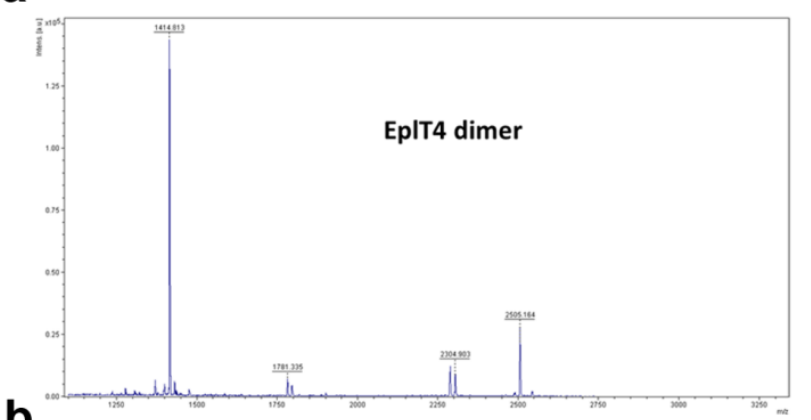

b

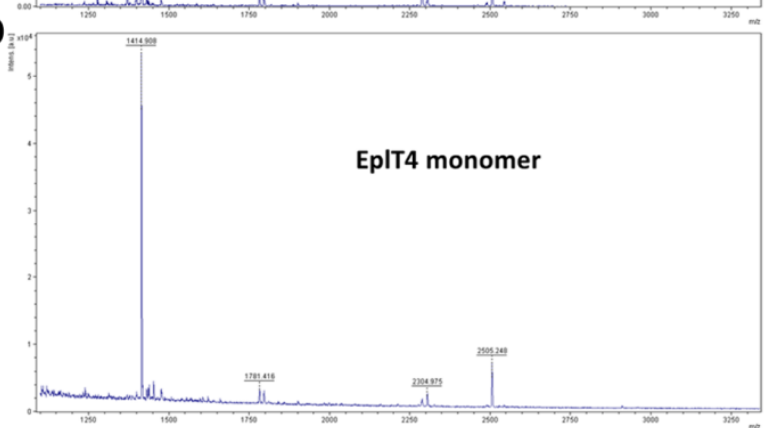

21

22

23

24

25

26

27

28

29

30

31

32

33 
2

3

4

5

6

7

8

9

10

11

12

13

14

15

16

17

18

19

20

21

22

23

24

25

26

27

28

29

30

31

32

33

34

35

36

37

38

39

40

41

42

43

44 b

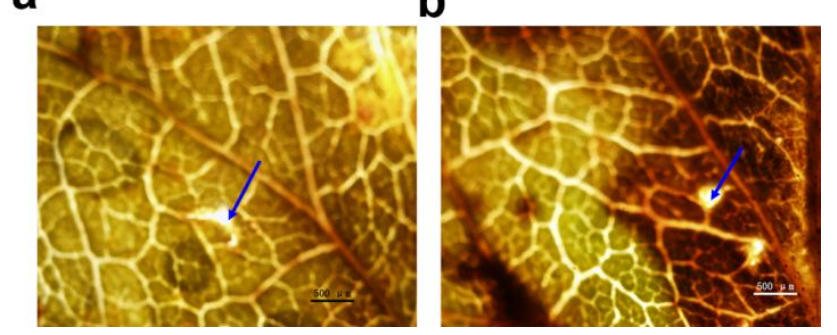

Fig. 5

.




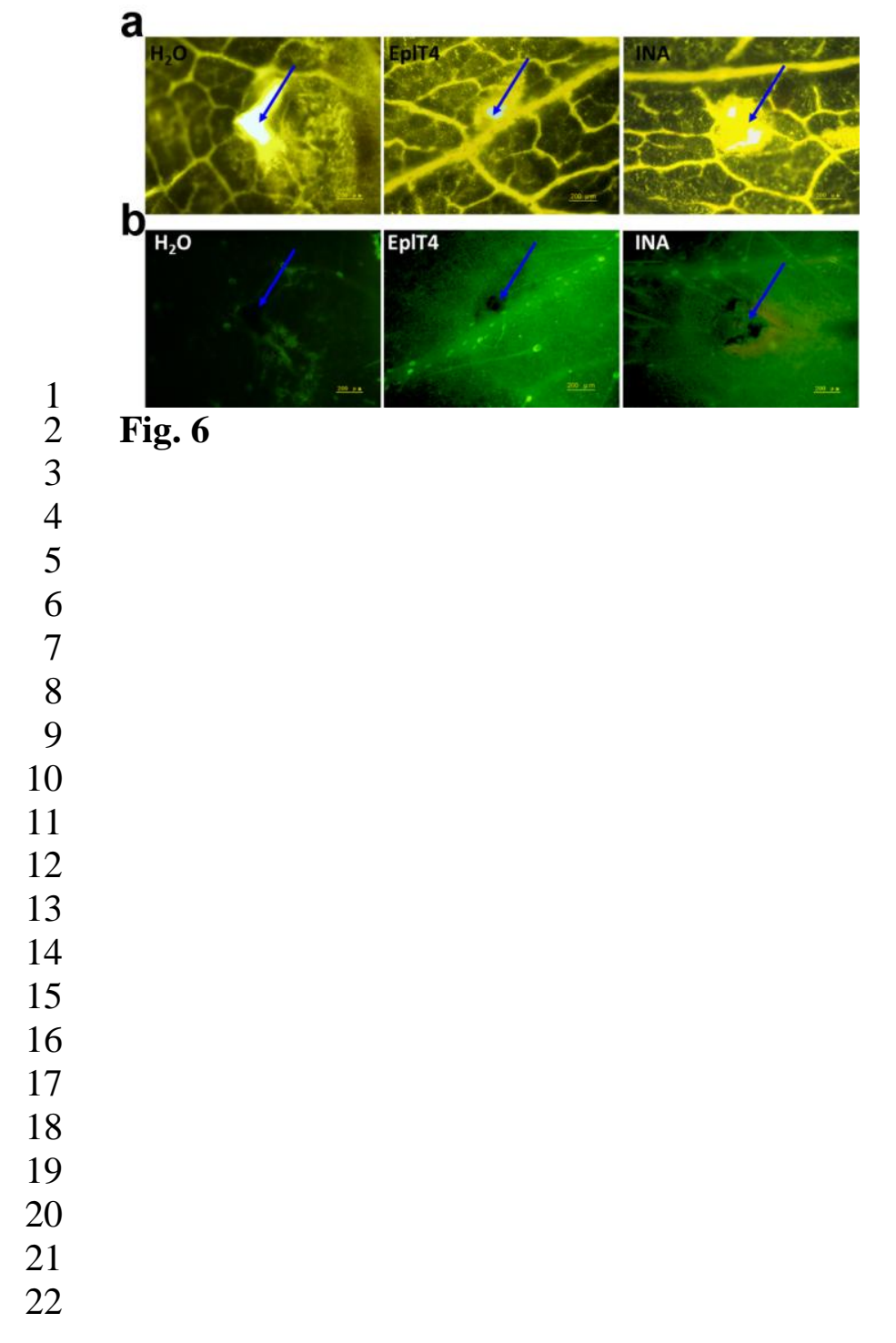




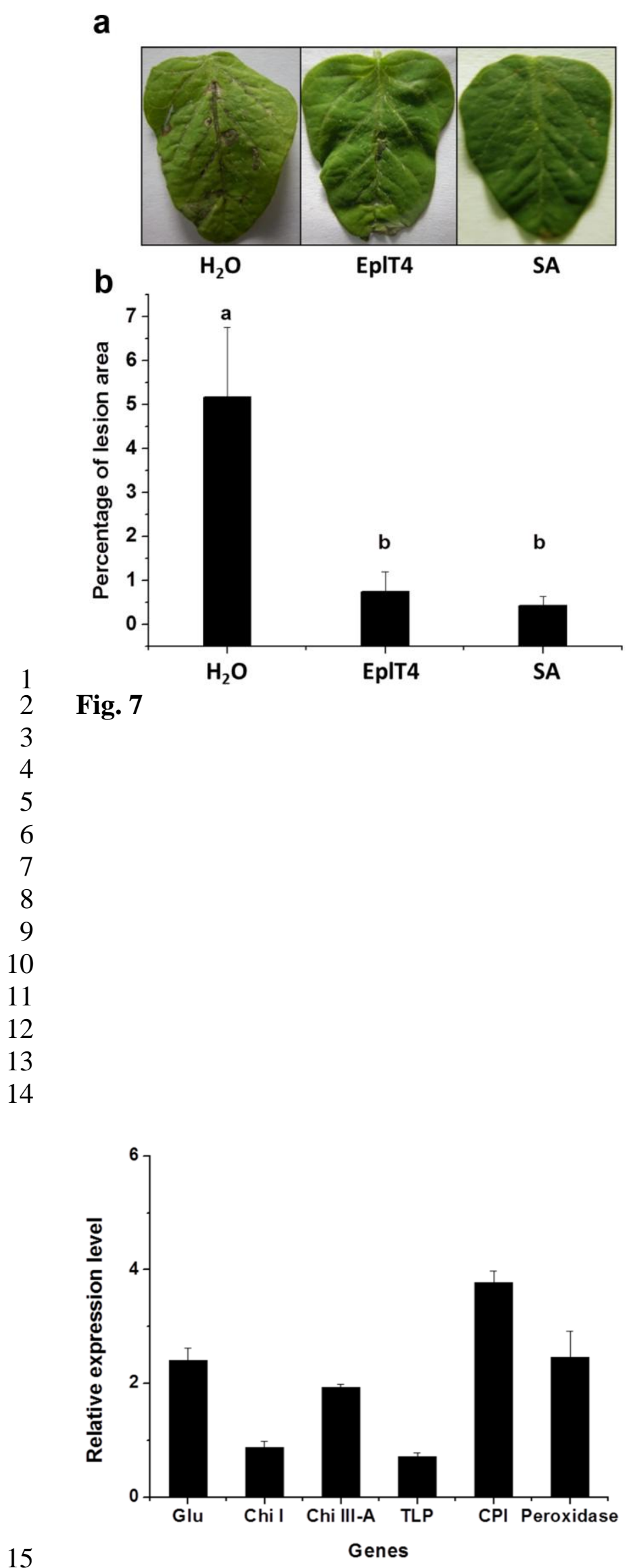

16 Fig. 8

17 
1 Table 1. Primers used in this study

2

\begin{tabular}{|c|c|c|c|}
\hline Gene/primer name & $\begin{array}{l}\text { GenBank } \\
\text { No. }\end{array}$ & $\begin{array}{l}\text { Family of } \\
\text { PR } \\
\text { protein }\end{array}$ & Primers (5'-3') \\
\hline Actin 11 & BW652479 & $\begin{array}{l}\text { internal } \\
\text { references }\end{array}$ & $\begin{array}{l}\text { ATTTTGACTGAGCGTGGTTATTCC } \\
\text { GCTGGTCCTGGCTGTCTCC }\end{array}$ \\
\hline $\begin{array}{l}\text { Thaumatin-like } \\
\text { protein }\end{array}$ & AB116251 & PR-2 & $\begin{array}{l}\text { AATGGCCGTCACGAAAAGC } \\
\text { TGAAGTTCGCTGCCTGAGCTA }\end{array}$ \\
\hline Chitinase I & AF202731 & PR-3 & $\begin{array}{l}\text { ATTTGGGTGGTGTGGTGACA } \\
\text { GTGTTGAGGGTGTTGCAGATTTG }\end{array}$ \\
\hline Chitinase III-A & AB006748 & PR-8 & $\begin{array}{l}\text { GAAGCTACTCCCTCAGCTCAGC } \\
\text { CCTAATGGCCCTGATCCAGTT }\end{array}$ \\
\hline Beta-1,3-glucanase & U08405 & PR-5 & $\begin{array}{l}\text { CCTCCCAATGATGGCGTTTT } \\
\text { GCCCCATTGCTCACTAGGAA }\end{array}$ \\
\hline $\begin{array}{l}\text { Cysteine proteinase } \\
\text { inhibitor }\end{array}$ & D31700 & PR-6 & $\begin{array}{l}\text { CCAACCTGGATGGCAATCTG } \\
\text { GCTGGATAGTCTTGATCGCATGAT }\end{array}$ \\
\hline Peroxidase & L78163 & PR-9 & $\begin{array}{l}\text { CAGGTGGTCATACGTTTGGAAGA } \\
\text { AGGGTTTCCAGTGTTGCTGAA }\end{array}$ \\
\hline P1 & & & $\begin{array}{l}\text { CGGAATTCGATACCGTCTCGTACG } \\
\text { ATACCGGCT }\end{array}$ \\
\hline $\mathrm{P} 2$ & & & $\begin{array}{l}\text { ATAAGAATGCGGCCGCTTAATGAT } \\
\text { GGTGATGGTGATGGAGGCCGCAGT } \\
\text { TGCTCACAGC }\end{array}$ \\
\hline $\begin{array}{l}\alpha \text {-factor primer } \\
3^{\prime} \text {-AOX1 primer }\end{array}$ & & & $\begin{array}{l}\text { TACTATTGCCAGCATTGCTGC } \\
\text { GCAAATGGCATTCTGACATCC }\end{array}$ \\
\hline
\end{tabular}

3

4

5

6

7 


\section{University Library}

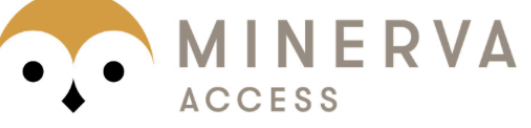

A gateway to Melbourne's research publications

Minerva Access is the Institutional Repository of The University of Melbourne

Author/s:

Wang, Y;Song, J;Wu, Y;Odeph, M;Liu, Z;Howlett, BJ;Wang, S;Yang, P;Yao, L;Zhao, L;Yang, Q

Title:

Eplt4 Proteinaceous Elicitor Produced in Pichia pastoris Has a Protective Effect Against Cercosporidium sofinum Infections of Soybean Leaves

Date:

2013-02-01

Citation:

Wang, Y., Song, J., Wu, Y., Odeph, M., Liu, Z., Howlett, B. J., Wang, S., Yang, P., Yao, L., Zhao, L. \& Yang, Q. (2013). Eplt4 Proteinaceous Elicitor Produced in Pichia pastoris Has a Protective Effect Against Cercosporidium sofinum Infections of Soybean Leaves. APPLIED BIOCHEMISTRY AND BIOTECHNOLOGY, 169 (3), pp.722-737. https://doi.org/10.1007/ s12010-012-0015-Z.

Persistent Link:

http://hdl.handle.net/11343/283084 